\title{
Progress in implementing the Water Framework Directive in the UK - barriers and opportunities
}

\author{
A. Meldrum \\ Glasgow Caledonian University, \\ School of the Built \& Natural Environment, UK
}

\begin{abstract}
In response to the EU Water Framework Directive (WFD), the UK environmental agencies are implementing a number of policy measures and programmes to ensure the requirements of the Directive are understood and can be met in timely fashion. This study explores progress to date in rolling out programmes and the barriers to their implementation that have been encountered by a variety of stakeholders in the UK.
\end{abstract}

Keywords: water quality, water regulation, significant water management issues.

\section{Introduction}

The Water Framework Directive (2000/60/EC) came into force on 22 December 2000. It established a new legal framework for the protection, improvement and sustainable use of all water bodies across Europe. The main environmental objectives of the Directive are to protect and improve the water environment, including the prevention of deterioration of aquatic systems and where possible, restoring surface waters and groundwater damaged by pollution, water abstraction, dams and engineering activities to 'good status' by 2015 .

\section{What do we need to do under WFD?}

The first activities were to set up river basin district structures within which demanding environmental objectives would be set, looking at all living things in 
the water environment. This was in order to identify significant water management issues and develop environmental standards by which we can measure its ecological health (Lewin and Burston [9]; MacDonald et al. [10]). The science base was to be developed first, and then costs of measures considered for fairness and proportionality. In many cases these basic requirements will not be available for the first River Basin Management Plans (RBMPs) to be developed for the WFD (UK Environment Agency [6, 7]; DOENI [5]; Scottish Environment Protection Agency [12, 13]). Economists, scientists and environmental managers need to work together over the long term to make sure the opportunities provided by the Directive are grasped.

\subsection{Classification and river basin planning}

Classification was a key stage of the WFD planning system. The RBMPs will contain maps which show the status of surface and groundwater bodies across the EU. The assessment of ecological status will be based on the level of departure from an undisturbed or reference condition. Good ecological status, the default objective for all water bodies, is equivalent to a slight deviation from the reference condition (Wildlife and Countryside Link [15]). The first cycle of the WFD RBM Planning process will culminate in RBMPs in December 2009. These will contain environmental objectives for each water body and a programme of measures (POMs) to help achieve them.

\subsection{Significant Water Management Issues (SWMI) and Heavily Modified Water Bodies (HMWB)}

SWMIs are those issues that pose the greatest risk to our ability to achieve the WFD environmental objectives. The process of identifying SWMIs was the first real stage of RBM planning and consultations took place during 2007 (UK Environment Agency [6]; Scottish Environment Protection Agency [12]). Heavily modified water bodies themselves represent an issue of significance to many stakeholders, the most complex issues being how good ecological potential is defined and how the bodies themselves are identified.

\section{Early Feedback from stakeholders}

In early feedback from the UK (Brook [3]), stakeholders shared the desire to meet the aims of the WFD whilst also taking full account of socio-economic interests; without compromising sustainable development opportunities. They hoped that the WFD would deliver truly integrated land and water management with necessary changes in water management practice and that there would be fair representation, local involvement, adequate resourcing and joined up thinking.

Stakeholders reflected that useful opportunities to become involved in the implementation process had been provided, both nationally and on Liaison Panels. There had been significant success in raising awareness, particularly in the agricultural sector and progress made with catchment farming and cross- 
compliance. However, there could have been better: data collection/collation; stakeholder engagement - more involvement with small stakeholders, wider group representation (planning and recreation), less emphasis on consultation as a substitute for real participation, more outreach from Liaison Panels to stakeholders; coordination between the many different elements of WFD implementation, in particular with the planning sector; more relaxed timescales and simpler requirements obviating a top down approach and the over application of corporate objectives, more resources for implementation of monitoring, measures and management.

Stakeholders called for improvements to ensure better representation of smaller stakeholders who lack the resources to contribute alone. Priority ought to be given to making adequate resources available to those who can 'make a real difference'. Better communications were needed, and improved coordination between the many different aspects of WFD implementation would both have practical benefits and improve confidence amongst stakeholders. In addition, clarity was asked for about how WFD measures will be funded and delivered. A simplified, user-friendlier approach to the presentation of the economics work would have been appreciated. It was thought that efforts to ensure wider consumer recognition of the WFD's objectives could help with both ownership of the problems and the delivery of solutions.

\section{EU Progress to date}

The WFD planning phase is now nearing closure and in preparation for the draft River Basin Management Plans (RBMPs) which are now being consulted upon, Member States were to identify and consult stakeholders about the Significant Water Management Issues (SWMI) that affect each River Basin. In 2007, the World Wildlife Fund for Nature (WWFN) and the EU Environment Bureau carried out a study into SWMI development across the EU. The results of the study echoed early feedback from UK stakeholders and their dissatisfaction with consultation as a substitute for real engagement, coupled with their inability to influence final documents. In particular there was concern about lack of transparency, scientific evidence and the vagueness of SWMI identification and decision making procedures. At the EU level, flow and morphological alterations were re-confirmed as the most important pressures on rivers by the background information provided in the consultation. However, identified SWMIs did not reflect the specific urgency of protecting and restoring river systems.

This current study investigates progress in the UK since the WWFN study and tries to identify what is working, any barriers to implementation and what more needs to be done to ensure compliance with the WFD by 2015 .

\section{Methodology}

This study took a largely qualitative approach, reviewing published information that has emerged as part of the WFD transparency and consultation processes being carried out in the UK. This was supplemented by responses from a variety 
of stakeholders to a questionnaire that probed the key aspects of WFD compliance management, including: classification and inter-calibration, river basin management planning, environmental objectives and standards and diffuse pollution.

The issues considered were: what works well so far, perceived barriers to implementation and what further needs to be done to ensure effective implementation and compliance with the WFD. Responses were patchy in that full representation of all parts of the UK was not present. However, agencies, NGOs, regulators and academia did input to the questionnaire and gave depth to information provided in publications.

\section{Findings}

Analysis of a range of publications from the agencies, regulators, NonGovernment Organisations (NGOs) and trade organisations, and other stakeholders reveals that the key pressures across the UK water environment are (in order of importance):

1. Diffuse pollution from rural (agriculture and forestry) and urban and transport run-off

2. Morphological issues due to modifications to estuaries and coasts, or rivers and lakes

3. Abstraction and other artificial flow pressures

4. Point source pollution, including industrial discharges and sewerage

5. Commercial fisheries, including shell fishing and aquaculture

6. Mines and mine waters

Tables 1 to 5 show the most significant current measures and the most commonly suggested future measures that could be implemented to comply with the WFD. Each RBMP and set of SWMIs were compared across the UK and the percentages reflect how many of the River Basin Districts are carrying out/planning the cited activities.

Water authorities were found to fail to grasp the urgency of climate change or prefer not to discuss it with NGOs and the public in the WWFN [17] study. This was not borne out by feedback from the water industry in the UK in this study (Aylford [1]). In fact, this was one of the key issues raised by water industry respondents that must be considered in determining roles and responsibilities for implementing measures to comply with the WFD. This is due to the close coupling of energy and water/wastewater treatment and the implication that water companies may be best placed to deal with many measures, despite potential costs to customers and the environment generally.

The lack of understanding of the interdependencies between human systems and ecosystem resilience to cope with environmental changes (Lewin and Burston [9]; MacDonald et al [10]; Shi et al [14]) was not specifically explored in this study, but few measures seem to consider it. 
Table 1: $\quad$ Rural diffuse pollution - current and future measures.

\begin{tabular}{|l|c|l|c|}
\hline Current measures & $\begin{array}{c}\text { \% RBs } \\
\text { doing this } \\
\text { activity }\end{array}$ & Further possible measures & \% RBs \\
\hline $\begin{array}{l}\text { Regulations/designation of Nitrate } \\
\text { Vulnerable Zones }\end{array}$ & 100 & & 44 \\
\hline $\begin{array}{l}\text { Pesticides Voluntary } \\
\text { Initiative/reduction in pesticide } \\
\text { use and marketing/crop protection } \\
\text { plans }\end{array}$ & 89 & $\begin{array}{l}\text { Extend voluntary initiative on } \\
\text { pesticides }\end{array}$ & \\
\hline Code of good agricultural practice & 78 & & 44 \\
\hline $\begin{array}{l}\text { Environmental Stewardship } \\
\text { Schemes with options for resource } \\
\text { protection/Greener futures support } \\
\text { to farmers on legal compliance }\end{array}$ & 78 & $\begin{array}{l}\text { Encourage better application of } \\
\text { Forest and Water Guidelines }\end{array}$ & \\
\hline $\begin{array}{l}\text { Catchment Sensitive Farming } \\
\text { Delivery Initiative }\end{array}$ & 78 & $\begin{array}{l}\text { Extended use of Catchment } \\
\text { Sensitive Farming to all } \\
\text { affected catchments }\end{array}$ & 67 \\
\hline $\begin{array}{l}\text { Water Protection Zone } \\
\text { Designation Order 1999 (controls } \\
\text { the storage of certain chemicals })\end{array}$ & 78 & $\begin{array}{l}\text { Increase enforcement of } \\
\text { existing banned pesticides } \\
\text { (including sheep dip) }\end{array}$ & 33 \\
\hline $\begin{array}{l}\text { Agri-environment schemes } \\
\text { Cross compliance obligations } \\
\text { under Single Farm payment rules }\end{array}$ & 78 & $\begin{array}{l}\text { Increase funding for agri- } \\
\text { environment schemes/targeted } \\
\text { support via Rural Development } \\
\text { Contracts (Scotland)/promote } \\
\text { local pilot schemes }\end{array}$ & 44 \\
\hline
\end{tabular}

Table 2: Urban and transport diffuse pollution - current and future measures.

\begin{tabular}{|c|c|c|c|}
\hline Current measures & $\begin{array}{c}\% \text { RBs } \\
\text { doing } \\
\text { this } \\
\text { activity }\end{array}$ & Further possible measures & $\begin{array}{c}\% \\
\text { RBs }\end{array}$ \\
\hline Regulatory control & 100 & General Binding rules & 56 \\
\hline $\begin{array}{l}\text { Promotion of sustainable urban } \\
\text { drainage schemes (SUDs) through } \\
\text { planning consultations for new } \\
\text { developments/ Regional Spatial } \\
\text { Strategy/Company Asset Management } \\
\text { Plans/Catchment Flood Management } \\
\text { Strategies }\end{array}$ & 100 & $\begin{array}{l}\text { Greater use of Sustainable Urban } \\
\text { Drainage Systems as part of new } \\
\text { developments and retro-fitting } \\
\text { where feasible -promotion of } \\
\text { Sustainable Drainage Systems } \\
\text { (SUDs) and more integrated } \\
\text { planning of urban drainage }\end{array}$ & 89 \\
\hline $\begin{array}{l}\text { Inclusion of urban drainage impacts in } \\
\text { Catchment Flood Management } \\
\text { Strategies }\end{array}$ & 89 & $\begin{array}{l}\text { The ability to factor the effect of } \\
\text { climate change into sewer design }\end{array}$ & 67 \\
\hline $\begin{array}{l}\text { Influencing planning policies on the } \\
\text { regional and local level in order to } \\
\text { promote resource efficiency, water } \\
\text { quality, drainage issues, infrastructure } \\
\text { requirements, sustainable construction } \\
\text { and design etc/RBMPs }\end{array}$ & 89 & $\begin{array}{l}\text { More practical Guidance/Best } \\
\text { Practice for Planners e.g. specific } \\
\text { adaptation measures in the field } \\
\text { of water management, flood risk } \\
\text { management etc, waste } \\
\text { management }\end{array}$ & 56 \\
\hline $\begin{array}{l}\text { Partnerships with water companies to } \\
\text { resolve misconnections of foul sewers } \\
\text { to surface water drains }\end{array}$ & 67 & $\begin{array}{l}\text { Develop Codes of Practice with } \\
\text { key sectors/ hazardous chemical } \\
\text { handling }\end{array}$ & 56 \\
\hline
\end{tabular}


The most common measures currently in place are abstraction controls and urban planning requirements followed by river and wetland restoration. New measures seem to gel with those identified in the EU study (WWFN [17]) which found that focus was on rural and agricultural land use and management requirements with removal of obsolete historic structures. NGOs in that study named the protection and restoration of floodplains, dam removal (in cases where their presence has significant ecological consequences and marginal benefits for energy production) and river restoration as their top priority measures, but noted that economic instruments are weak or non-existent (Bouleau [2]) and that agencies prefer voluntary instruments.

Table 3: $\quad$ Morphological issues - current and future measures.

\begin{tabular}{|c|c|c|c|}
\hline Current measures & $\begin{array}{l}\text { \% RBs } \\
\text { doing } \\
\text { this } \\
\text { activity }\end{array}$ & Further possible measures & $\begin{array}{c}\% \\
\text { RBs }\end{array}$ \\
\hline $\begin{array}{l}\text { Influencing Planning Policy Guidance/ } \\
\text { Control, regional and development plans, } \\
\text { so that regeneration and redevelopment } \\
\text { are used as an opportunity to provide } \\
\text { space for recreating 'natural' river } \\
\text { corridors - limit inapt development }\end{array}$ & 78 & $\begin{array}{l}\text { Extend promotion of river } \\
\text { naturalisation through the } \\
\text { development planning } \\
\text { process/raise awareness to } \\
\text { prevent bank damage by river } \\
\text { traffic/modify } \\
\text { drainage/prioritise problematic } \\
\text { impoundment and address } \\
\text { these under our new powers } \\
\text { under the Water Act } 2003 \text {. }\end{array}$ & 44 \\
\hline $\begin{array}{l}\text { Developing Catchment Flood } \\
\text { Management Plans, which set the future } \\
\text { direction for sustainable flood risk } \\
\text { management/drainage EIA }\end{array}$ & 67 & $\begin{array}{l}\text { Develop further river and } \\
\text { flood plain restoration } \\
\text { schemes/flood } \\
\text { management/consider } \\
\text { regulation (Scotland) }\end{array}$ & 67 \\
\hline $\begin{array}{l}\text { Regulate dredging and disposal of } \\
\text { material, both for new developments and } \\
\text { regular maintenance is already regulated. } \\
\text { This includes the production of } \\
\text { Environmental Impact Assessments/ } \\
\text { Sustainable dredging framework for tidal } \\
\text { areas/ CAR }\end{array}$ & 56 & $\begin{array}{l}\text { Review and refine dredging } \\
\text { programmes for best practice } \\
\text { Use of softer flood risk } \\
\text { reduction measures, hence } \\
\text { reducing the need for localised } \\
\text { hard defence construction }\end{array}$ & $\begin{array}{l}56 \\
67\end{array}$ \\
\hline $\begin{array}{l}\text { Implement River and floodplain } \\
\text { Restoration Strategies to re-instate } \\
\text { degraded river habitats in both urban and } \\
\text { rural catchments - development } \\
\text { management processes }\end{array}$ & 56 & $\begin{array}{l}\text { Develop further river and } \\
\text { flood plain restoration } \\
\text { schemes/ consider regulation } \\
\text { (Scotland) }\end{array}$ & 78 \\
\hline
\end{tabular}

This is borne out by this study and is shown in Tables 1 to 5 . Any new infrastructure planning (Scottish Environment Link [11]) that might conflict with WFD objectives was not deemed to be addressed. Evidence from this study seems to support this argument.

Although partnership and influence by the agencies on Water Company and planner decision making are highlighted (CIWEM [4]), measures do not seem to include consideration of how measures will be funded or whose role/responsibility it is to execute measures. 
Table 4: $\quad$ Abstraction and flow issues - current and future measures.

\begin{tabular}{|c|c|c|c|}
\hline Current measures & $\begin{array}{l}\% \text { RBs } \\
\text { doing this } \\
\text { activity }\end{array}$ & Further possible measures & $\begin{array}{c}\% \\
\text { RBs }\end{array}$ \\
\hline $\begin{array}{l}\text { Regulation through abstraction } \\
\text { licensing (Water Resources Act } \\
\text { 1991, Water Act 2003, Fisheries } \\
\text { Act, etc)/ review through Habitats } \\
\text { Directive }\end{array}$ & 67 & $\begin{array}{l}\text { Increased promotion of } \\
\text { abstraction during winter period } \\
\text { and storage until required in } \\
\text { appropriately sited reservoirs }\end{array}$ & 33 \\
\hline $\begin{array}{l}\text { Asset Management Plan } \\
\text { investigations funded by water } \\
\text { companies e.g. the investigation into } \\
\text { low-flow/leakage issues } \\
\text { limestone/Water resource } \\
\text { plans/leakage reduction targets }\end{array}$ & 56 & $\begin{array}{l}\text { Further/more effective demand } \\
\text { management/ use future rounds } \\
\text { of the Asset Management Plan } \\
\text { (AMP) process to deliver more } \\
\text { sustainable abstractions }\end{array}$ & 33 \\
\hline $\begin{array}{l}\text { Water efficiency workshops for } \\
\text { spray irrigators/homes and gardens, } \\
\text { agriculture and industry }\end{array}$ & 56 & $\begin{array}{l}\text { Water efficiency measures as } \\
\text { well as energy efficiency in all } \\
\text { new building/ Building } \\
\text { standards for rainwater capture } \\
\text { and recycling for garden use and } \\
\text { toilet flushing }\end{array}$ & 44 \\
\hline $\begin{array}{l}\text { Development of Catchment } \\
\text { Abstraction Management Strategies } \\
\text { (CAMS), which are a tool to identify } \\
\text { the availability of water/catchment } \\
\text { risk assessment }\end{array}$ & 44 & $\begin{array}{l}\text { Installation of meters in water } \\
\text { stressed areas/decrease demand } \\
\text { in homes and businesses }\end{array}$ & 33 \\
\hline
\end{tabular}

Table 5: $\quad$ Point source pollution - current and future measures.

\begin{tabular}{|c|c|c|c|}
\hline Current measures & $\begin{array}{c}\% \text { RBs } \\
\text { doing this } \\
\text { activity }\end{array}$ & Further possible measures & $\begin{array}{c}\% \\
\text { RBs }\end{array}$ \\
\hline $\begin{array}{l}\text { Regulation through Pollution } \\
\text { Prevention and Control } \\
\text { Regulations, EPA } 1990 \text { Part 2A, } \\
\text { UWWT Directive 1991, Habitats - } \\
\text { review consents/CAR/Waste } \\
\text { management Regs }\end{array}$ & 89 & $\begin{array}{l}\text { Promote changes in industrial } \\
\text { processes in order to reduce the } \\
\text { load or concentration of the } \\
\text { emission/voluntary or regulatory/ } \\
\text { pollution prevention visits to } \\
\text { industrial sites. }\end{array}$ & 33 \\
\hline $\begin{array}{l}\text { Regulation of discharge consents } \\
\text { through the Water Resources Act } \\
1991 \text { (as amended) }\end{array}$ & 67 & $\begin{array}{l}\text { Targeted Pollution Prevention } \\
\text { Campaigns/revise consents } \\
\text { through the Water Resources Act } \\
\text { to achieve new UKTAG standards }\end{array}$ & 33 \\
\hline
\end{tabular}

Clearly, compliance with other Regulations that deal with issues in the water environmental will help to underpin the effectiveness of measures taken with respect to the WFD. Point source pollution is heavily regulated already and promotion of source controls and education about the fate of effluents is intended to encourage increased industrial management of discharges to the water environment.

Not all RBMPs consider fisheries in a focused way. Equally, mines and minewaters are not present in every area so that these pressures are not reflected in this paper. 


\subsection{Feedback from the questionnaire}

\subsubsection{Integration aims}

There is wide variation in opinion on this topic. 54\% of respondents believe that integration aims are being at least partially addressed. However, it is believed that the lack of determination of roles and responsibilities of the various stakeholders and lack of knowledge are limiting effective action at this time. Lack of data and lack of involvement of planning authorities appear to be holding up integration of water and land use planning. Cross sector working will be crucial to successful compliance with the WFD.

Perceived barriers to implementation include funding, technical feasibility, and complexity of regulation for agriculture in some areas (Scotland in particular), although a growing awareness in the farming community about protecting and conserving water resources is perceived. Liaison panels are working, but respondents call for greater cross-functional working and consideration of socio-economic issues, in particular in the farming sector. Increased education, collaboration and clarity of roles and responsibilities across stakeholders are seen as key foci going forward, with the development of effective funding and delivery mechanisms that can be seen to be fair handed and sustainability oriented being crucial to timely and effective implementation.

\subsubsection{Classification and inter-calibration}

Initial barriers included finding new ways to work with stakeholders and effectively engage with new contacts to ensure transparency and pooling of knowledge and expertise. Lack of, or costly to gather data is a fundamental barrier for some sectors. The 'one out all out' principle is not uniformly well received and is seen to perhaps mask the picture of underlying ecological health of the water environment. Monitoring networks are perceived to be limited and mainly based on rivers, so giving a skewed picture of the overall water environment. $56 \%$ of respondents believe that calibration is working at least partially and the agencies seem to have benefited from the EU inter-calibration process and having benchmarks in place. Free data exchange is seen as a necessity, particularly for smaller organisations who have never gathered this type of data before. Limitations on data have caused simplification of analysis of ecological status and this poses potential risk and a need to progressively validate local information.

\subsubsection{River basin structure and planning}

$80 \%$ of respondents view this aspect of planning as at least partially working. The role of the water industry is well framed, although it (and its customers) cannot carry the costs for all measures that it might be the best implementer of. Decision making structures need to be clarified and resources allocated fairly across hard and soft measures, particularly when the actual polluter is hard to identify. There is concern about extended deadlines and plans with too few measures directed at getting individual water bodies to good status. 


\subsubsection{Environmental objectives and standards}

There is broad approval for proposed actions in the RBMPs with 57\% of respondents perceiving that environmental objectives and standards are at least partially appropriate. However there is concern about assessing good status from a biological standpoint. By not focusing on biology, separate from physicochemistry, the number of water bodies achieving good status is lower than figures are currently suggesting.

Developing standards for ecology and morphology have proved to be an initial barrier, so the previous observation seems to be supported. Some costs seem to be disproportionate and some standards are currently not technically feasible and this begs the question of whether objectives should emerge as knowledge and experience increases rather than setting such challenging standards at the start of the RBM process. Another key issue is the failure to apply Article 4.2 by imposing derogations for some Natura sites without thorough analysis or justification. HMWB designations are still unclear, making it difficult to assess the likely effectiveness of measures for them. The size of the task and the emergence of new quality elements, in some cases without associated standards for ecological health, mean they cannot be included in some classifications.

The good news is that UK water quality is already improving and there is consistency in standard setting across the EU, although standards in biota and sediment for persistent chemicals are not yet set for Europe. Guidance on objective setting is clear but it is early days for implementation and further work on standards development is needed. Consultation has revealed that in some areas tighter standards and a more precautionary approach; particularly for rivers, would be preferred.

\subsubsection{Diffuse pollution}

There is divided opinion on whether diffuse pollution is being managed well. Initial barriers to implementation have been the challenges in identifying land use linkages. The impact of different types of pressure on diffuse pollution (abstraction, morphology, etc.) is equally challenging to get to grips with. Causality identification is crucial but can eat up resources and synergistic effects of individual components in the environment can be complex to understand, so that establishing potential degree of harm; and the polluter, is complicated. Application of the polluter pays principle will help to fairly allocate costs, but the polluter can be difficult to find without sound scientific evidence as to sources of pollutants. Further work on sources, pathways and impacts is required to ensure that measures are properly targeted. More education is needed about control of pollution at source, rectification of run-off pathways, effective fish farm management and how to set up and maintain SUDS to prevent bad practice.

\subsubsection{Significant water management issues}

Initial barriers were identifying and assessing HMWBs for the first time for the purposes of objective setting. This was completely new work to set up processes for assessment at the start. Half the respondents believe that this process has 
gone well so far, and certainly there have been a wide range of actions taken and suggested to manage these risks and impacts, which have been incorporated in the draft RBMPs.

The impact of climate change and energy requirements for, in particular, the water industry should not be underestimated. Many companies will need to assess how they will achieve quality improvements required by the WFD and other Directives, whilst reducing emissions and cutting back on energy usage. Source controls, such as better catchment management, coupled with well designed water treatment practices involving less energy and chemicals should be investigated, rather than quick fixes to meet WFD objectives. Lake restoration is an important area that needs immediate work. Many lakes suffer eutrophication and/or silting and there is no funding source for their restoration.

\subsubsection{Policy framework}

Initial barriers focus around cross-functional working which in the past was very limited. Parliamentary timetables and recession seem to be barriers for some respondents and a need for flexibility in RBM planning and objective setting are crucial. A realistic approach to environmental objectives and pace of delivery, improvements that deliver value for money relative to risk involved, fair and proportionate responsibility for action and costs and timing of implementation to available information and experience are also cited as important to effective and sustainable implementation. Guidance generated from working with EU CIS, UKTAG (UK Technical Advisory Group) and Defra has proved very useful and liaison panels have made significant contributions, despite not being able to engage or consult all stakeholders consistently. Future work should include more precautionary standards for nutrients, clarity over exemptions and guidance on protected areas.

\subsubsection{Cost Effectiveness Analysis (CEA)}

For many, cost effectiveness analysis has been complicated by lack of information about costs and measures. There has been no discussion of opportunity cost incurred by pollution or what happens if a measure fails due to unforeseen synergistic effects, e.g. for diffuse pollution, nor how the analysis of costs for measures is made and who benefits from decisions made on measures. The principle ought to be that CEA should support the choice from a range of measures, but often there is only one measure to choose from. It is clearly early days for this type of analysis and the uncertainty in responses reflects this. Collaborative research on CEA has led to the development of tools to facilitate the process used in the development of RBMPs. Further work is needed over subsequent cycles to understand causes and effectiveness of some measures and other forms of evaluation and more inclusive, grassroots forms of decisionmaking need to be explored.

\subsubsection{Resources for implementation}

Responses showed $(80 \%)$ that resources for implementation of the WFD are not deemed sufficient as yet. This has a lot to do with uncertainty about what more needs to be done, how measures will work on the ground and whether they will 
be successful, cost effective and proportionate. There is a high degree of uncertainty about how much resource is needed to achieve WFD goals at this time and only as the first RBM plans are executed will the true level of resource and finance needed become apparent. Barriers to implementation from the perspective of resource are currently unknown and the impact of recession and public sector funding cutbacks are likely to have an impact on resources that can be made available for implementation. These factors are as yet unquantified in their impact on ability to implement the Directive.

The planning phase for RBM is still in train and resource availability will become clearer during the implementation phase from 2010 onwards. The start up of programmes on new elements of good ecological status and actual restoration/controls of invasive species will require further stakeholder engagement in order to pool resources in the current economic climate.

\subsubsection{Public engagement and awareness raising}

Transparency, engaging all stakeholders and communicating with the public are requirements of the WFD (Woods [16]; WWFN [17]). However, many documents and in particular consultation documents would not be readable by anyone less than a well-informed individual with some technical knowledge. This means that only an informed or technical person could divine what is being done to comply with the Directive. This will limit engagement only to those who have a vested interest in the implementation of the Directive. In summary, $50 \%$ of respondents do not think engagement is working and a further $16 \%$ think it works only partially. Clarity and simplicity of communications are required in order to fully engage and be fully transparent, so there is clearly much work to be done with respect to this aspect of implementation.

\section{Conclusions}

In summary, the preparation stages of WFD implementation are complete and at the end of 2009 the RBMPs will be in place. For many stakeholders the preparation stages have raised challenges and opportunities to influence the implementation process. The main barriers to implementation thus far have been:

- Developing new tools where none previously existed (classification, economic, risk assessment)

- Monitoring for new elements not previously considered (ecology and morphology)

- Developing cross functional assessments of pressures, risk and impacts to enable co-delivery of the WFD across partners

- Costs of data gathering/overcoming IPRs for data sharing

- Consultation used instead of real engagement, which has excluded smaller stakeholders and some experts in certain fields

- Lack of clear identification of roles and responsibilities in delivering measures. 
Opportunities:

- Increased and wider engagement with documents written in language an intelligent but uninformed person can understand and interpret (as done for environmental statements)

- Free data exchange and more financial incentives

- Clear roles and responsibilities for measure delivery coupled with fair apportionment of cost burdens and embedding of the polluter pays principle

- Clear decision making structures

- Increased linkages with land use planning

- Sound scientific understanding of synergistic effects of substances in the water environment

- Tighter standards and more precautionary approach

- Increased education of the public and industry about the fate and impacts of wastewaters and tighter requirements to reduce the impact of discharges to the water environment

- More detailed consideration of lake restoration

In summary a great deal of progress has been made and the coming implementation phase will no doubt produce more information and understanding of water issues as data is gathered and experience in carrying out measures and their effectiveness is gained. However, there are some fundamental policy, structural and economic issues that need to be addressed if delivery of WFD aims is to be assured.

\section{References}

[1] Aylford, R., Protecting and improving the water environment. Response to Blueprint for Water. Thames Water, 2007.

[2] Bouleau, G., The WFD Dreams: Between ecology and economics. Water \& Environment Journal 22, pp. 235-240. 2008.

[3] Brook, J., Stakeholder views on WFD. Paper presented at CIWEM conference on Progress and implementing the WFD, June $26^{\text {th }} 2007$.

[4] CIWEM., Catchment management, land-use and water. CIWEM, September 2006.

[5] DOENI., Water matters - have your say. Consultation for Northern Ireland River Basin Districts. Department of Environment Northern Ireland, 2009.

[6] UK Environment Agency (a). River basin planning: working together. Responses to consultation on WFD from the River Basin Districts. 2006.

[7] UK Environment Agency (b). Beyond regulation: Non-legislative mechanisms for implementing the Water Framework Directive.2006.

[8] Hall, J., Scotland's water: Future directions. Implementing the Water Environment and Water Services (Scotland) Act 2003. National Farmers Union (NFU) consultation response, 4 April 2009 
[9] Lewin, K \& Burston, P., Water, Life and Framework Directive. Paper presented at CIWEM conference on Wetlands and the Community, London, 31 January 2002.

[10] MacDonald, MA, Densham, JM, Davis, R \& Armstrong-Brown, S., Forcefeeding the countryside: the impacts of nutrients on birds and other biodiversity. Evidence review. RSPB May 2006.

[11] Scottish Environment Link., Water Framework Directive and flooding Implications for flooding policies in Scotland. A Policy Statement by Freshwater task Force of the Scottish Environment Link, May 2005

[12] Scottish Environment Protection Agency., Significant water management issues in the Scotland river basin district. 2007

[13] Scottish Environment Protection Agency., The Dee/Ken catchment management plan. Issue review 2008.

[14] Shi, J, Davis, R \& Densham, J., Better land for better water: Scenarios for change. Modelling changes in agriculture to improve water quality in England. World Wildlife Fund for Nature/Royal Society for the Protection of Birds/WaterUK, February 2006.

[15] Wildlife \& Countryside Link., Response to consultation on Directions from the Environment Agency for Classification of Water Bodies, December 2008.

[16] Woods, D., Stakeholder involvement and public participation: a critique of Water Framework Directive arrangements in the United Kingdom. Water \& Environment Journal 22, pp. 258-264, 2008.

[17] World Wildlife Fund for Nature., Letting the public have their say on water management. Snapshot report. WWFN and EU Environmental Bureau. EEB Publication 2008/006. 